\title{
Editorial
}

\section{Faith-based governance}

\author{
International Journal of Disclosure and Governance (2010) 7, 4-6. doi:10.1057/jdg.2009.28
}

Recently on American television, it was reported that Ms Brooksley Born, Chair from 1996 to 1999 of the Commodity Futures Trading Commission - one of the smaller and more obscure US government regulatory agencies - had a lunch early in her tenure with Alan Greenspan, the then Chair of the Federal Reserve, at which Greenspan made the extraordinary comment that preventing financial 'fraud wasn't something that needed to be enforced or was something that regulators should worry about' because markets were 'self-correcting'. ${ }^{1}$ Ms Born strenuously disagreed with this position and repeatedly warned that, on the contrary, strong regulation of the emerging derivatives market was essential to avoid a future market meltdown. Unfortunately, history shows that her attempts to increase regulatory oversight of those markets were completely and brutally stymied by more senior regulators, including Greenspan, soon to be Treasury Secretary Larry Summers and then SEC chair Arthur Leavitt. And this after the collapse of Long Term Capital Markets in 1998 reinforced Born's argument that derivatives posed enormous risks to banks and the taxpayers who would have to bail them out if disaster struck.

This remarkable story, told in the powerful television broadcast aptly entitled 'The Warning', is worth pondering as the credit crisis that Ms Born feared a decade earlier goes on and on. ${ }^{2}$ While the Euro-zone and the USA may officially be out of recession, unemployment remains tragically high and national debts are increasing at a rate not seen since the Second World War. In the light of this continuing disaster, what is quite unexpected is the almost total absence of new regulations imposed in the USA on the financial sector in the aftermath of the crisis. ${ }^{3}$ And with more than a year having passed since the crisis began, there is growing skepticism that there is now the political will to impose the kind of sweeping reforms that seemed inevitable during the panic of October 2008. Indeed, the very same banks that were rescued with tens of billions of taxpayer dollars a year ago are now spending vast amounts to lobby Congress against imposing any further regulations on them.

Part of the reason for this lack of action in the USA is the continuing belief by many influential individuals in government and on Wall Street in the power of free markets to regulate themselves, a belief that, while it may not be taken to the laissez faire extreme of Chairman Greenspan, is an enduring stream in American economic life.

This attitude was evident in oral arguments heard recently before the US Supreme Court. The highly anticipated Jones v. Harris Associates case deals with the actions of the board of directors of mutual funds when agreeing on fees paid to the investment managers of the fund. The board of Harris Associates agreed to pay fees that were multiple times higher than the fees paid by other institutional investors to the same managers for providing the same services, a discrepancy that raises the question of whether the board of directors was exercising its fiduciary responsibility to the mutual fund investors. ${ }^{4}$

What I wish to draw your attention to was the comment by Chief Justice John Roberts during the oral hearing when he put forward 
a variant of the argument that market forces were sufficient to discipline boards of directors and that hence, court imposed rules were unnecessary: These days all you have to do is push a button and you find out exactly what the management fees are. You just look it up on Morningstar and its right there, and as an investor you can make whatever determination you'd like, including to take your money out. Chief Justice Robert's argument, one that echoes those made in earlier courts dismissing the lawsuit, is that informed markets can self regulate, with the proviso that investors have to actively participate in policing their investments - or accept the consequences if they fail to do so.

Now it is undoubtedly the case that our system of governance does depend on at least some portion of investors being active and actively attempting to influence the management of the companies they invest it, rather than simply passively diversifying or divesting their holdings. However, not all investors are Warren Buffet, and the Chief Justice's argument seems to ignore the implications of transaction costs: achieving good governance is something that only has to be done once for each firm and there are large social costs to having each investor feeling obligated to do so themselves, or else being resigned to, hopefully, being a free rider on someone else's initiative. Ironically, this year's Nobel Prize in the Economic Sciences went to Oliver Williamson whose seminal work is precisely on the topic of how those transaction costs impact the form of organizations. Williamson's point is that sometimes it is efficient to internalize an external market relationship in order to reduce costs and informational asymmetries, which is why, for example, firms vertically integrate core functions. By the same argument, it has to be at least asked whether the best way of running a mutual fund is to leave it to individual investors to police investment managers or whether the job can be done better by the board of directors.

This journal has always paid a great deal of attention to the institution of the board of directors precisely because of the belief that it deserves respect as a mechanism that has evolved over the centuries to reduce the conflicts of interests between shareholders and professional managers at the lowest possible cost. It is certainly the case that if sufficient investors spent enough time monitoring mutual fund fees (and technology undoubtedly makes those fees more visible and easier to act upon) then perhaps boards will negotiate harder over fees. But then why have boards at all, if they are presumed not to act as fiduciaries until pressured by the threat of withdrawal of funds? A well-functioning board distills the interests of shareholders and directs them in an efficient way toward achieving an alignment of those interests with those of management. Market forces may discipline boards and managers, but that is a diffuse and hence expensive and wasteful policing device compared to other more direct governance mechanisms.

That is even more evident in the case of fraud. The Greenspan argument is that it can be left to markets to direct investments away from known or suspected fraudsters, and that in any case, fraud is a zero sum game and hence there is no real harm in it. Of course, by that same argument a mugging is also a simple transfer of wealth, no different than someone giving money to a charity or buying toothpaste at a store. The problem that economic rationalists such as Greenspan and his like from the University of Chicago school face is that the great majority of people are evidently not so rational. To them fraud in the market, like crime on the street, undermines their confidence in society and their trust in their ability to control their own destiny. And as we saw in October 2008, losses of confidence in markets can have catastrophic consequences. In other words, fraud, like other forms of bad governance, creates an externality, which is a clear market failure - and if the role of regulators is not to reduce the social cost of market failures, then why have regulation at all?

The rationale for this journal is that the governance and disclosure practices should 
arise from rigorous study and analysis of business and the law, rather than being based on tradition or unstated assumptions. Blind faith in one mechanism or another is antithetical not just to a reasoned examination of what works when and what does not, but to common sense. It may astonish and even dismay our readers that people as high placed and powerful as Allan Greenspan could have held the views as communicated to Ms Born. But that is all the more reason for this journal to continue its mission.

And there are grounds for optimism that over time even true believers in an ideology will acknowledge the reality on the ground. Thus, in the aftermath of the credit crisis, Allan Greenspan, publicly perceived today as more the villain in the piece as opposed to his prior exalted status as the world's greatest central banker, issued a mea culpa about his faith in unregulated free markets to a congressional hearing:

Referring to his free-market ideology, Mr Greenspan added: 'I have found a flaw. I don't know how significant or permanent it is. But I have been very distressed by that fact'. [Congressman] Mr Waxman pressed the former Fed chair to clarify his words. 'In other words, you found that your view of the world, your ideology, was not right, it was not working, $\mathrm{Mr}$ Waxman said. 'Absolutely, precisely', $\mathrm{Mr}$ Greenspan replied. 'You know, that's precisely the reason I was shocked, because I have been going for 40 years or more with very considerable evidence that it was working exceptionally well'. ${ }^{5}$

In 2010 the journal begins its seventh year of publication, focusing, as it has from its inception, on the science and art of governance. The articles in this issue include a masterly examination of the role that governance failings played in the credit crisis, a summary of the UK Walker Report, an analysis of the Jones v. Harris Associates case and a study of best practices in director compensation. I trust that our readers will continue to see this journal adding value in their own efforts to understand and improve governance and disclosure around the world based on a rigorous examination of the evidence and the application of common sense, rather than blind faith.

\section{NOTES}

1 www.pbs.org/wgbh/pages/frontline/warning/ interviews/greenberger.html\#1.

2 This program can be seen at the moment in streaming video at www.pbs.org/wgbh/ pages/frontline/warning/and I highly recommend that our readers see it for themselves.

3 By contrast, in the United Kingdom the report on the implications of the credit crisis on bank governance prepared by Sir David Walker has proposed significant changes, and there is the likelihood that at least some of those proposals will be implemented. Richard LeBlanc has an excellent article in this issue of the journal summarizing the Walker report, and the title of his paper makes his opinion about these proposals quite clear: 'The Walker Review Proposes "The Toughest Governance Regime in the World",

4 The issues at stake in this case are superbly summarized in the article in this issue by the famed governance scholar and practitioner Tamar Frankel.

5 www.economix.blogs.nytimes.com/2008/ 10/23/greenspans-mea-culpa/.

Michael Alles

Editor 